\title{
Temporal variation in the biomass and nutrient status of Azolla filiculoides Lam. (SALVINIACEAE) in a small shallow dystrophic lake
}

\author{
Variação temporal de biomassa e estado nutricional de Azolla filiculoides Lam \\ (SALVINIACEAE) em um pequeno lago raso distrófico
}

Claudio Rossano Trindade Trindade, Edélti Faria Albertoni and Cleber Palma-Silva
Programa de Pós-graduação em Biologia de Ambientes Aquáticos Continentais - PPG-BAC, Universidade Federal do Rio Grande - FURG, Av. Itália, Km 08, s/n, campus Carreiros, CEP 96201-900, Rio Grande, RS, Brazil e-mail: claudio.trindade@furg.br; dmbefa@furg.br; dmbcps@furg.br

\begin{abstract}
Aim: This study determined the temporal variation of the biomass and the concentrations of carbon, nitrogen and phosphorus in Azolla filiculoides Lam. in a small (0.5 ha) shallow dystrophic lake located in the city of Rio Grande (Rio Grande do Sul State, Brazil). Method: Sampling was conducted monthly between November 2000 and October 2001. The macrophytes were collected randomly in three replicates with a circular collector $0.3 \mathrm{~m}$ in diameter and subsequently washed with tap water and oven-dried at $60{ }^{\circ} \mathrm{C}$ for determination of the dry weight and the nutrient status (i.e., carbon, nitrogen and phosphorus). Primary productivity was estimated by the variation in biomass among successive samples. Results: A. filiculoides was present in the lake throughout the year and occupied between 50 and $80 \%$ of the surface area. The biomass values ranged from $34.2 \mathrm{~g} \mathrm{DW} . \mathrm{m}^{-2}$, recorded in May (autumn), to $170.9 \mathrm{~g} \mathrm{DW} . \mathrm{m}^{-2}$ in January (summer). The highest rate of primary productivity was $3.3 \mathrm{~g} \mathrm{DW} \cdot \mathrm{m}^{-2} \cdot \mathrm{d}^{-1}$, observed in June. The concentrations of carbon, nitrogen and phosphorus in the plant ranged between 403 and $551 \mathrm{~g} . \mathrm{kg}^{-1}, 13.4$ and $25.7 \mathrm{~g} . \mathrm{kg}^{-1}$ and 0.5 and $1.9 \mathrm{~g} . \mathrm{kg}^{-1}$, respectively. The water N:P ratio ranged between 19:1 and 368:1. Conclusion: The coverage of the surface of the lake by $A$. filiculoides throughout the study period and the nutritional status of the plant demonstrate the importance of the cycling of nutrients by macrophytes in this aquatic environment. The higher N:P ratio in the water column, compared with other neighboring environments without macrophytes, shows that the enrichment of the lake may result from the biological $\mathrm{N}$-fixation activity produced by $A$. filiculoides.
\end{abstract}

Keywords: primary production, floating macrophytes, carbon, phosphorus, nitrogen.

Resumo: Objetivo: Este estudo determinou a variação temporal da biomassa e as concentraçôes de carbono, nitrogênio e fósforo de Azolla filiculoides Lam., em um pequeno lago raso distrófico situado no município do Rio Grande (Rio Grande do Sul, Brasil). Método: As amostragens foram realizadas mensalmente no período entre novembro de 2000 e outubro de 2001. As macrófitas foram coletadas aleatoriamente em três repetiçóes, utilizando-se coletor circular de $0,3 \mathrm{~m}$ de diâmetro e posteriormente lavadas com água corrente e secas em estufa $60^{\circ} \mathrm{C}$ para determinaçáo do peso seco e dos nutrientes: carbono, nitrogênio e fósforo. A produção primária foi estimada pela variação de biomassa entre coletas sucessivas. Resultados: A. filiculoides esteve presente no lago durante todo o ano, ocupando sempre entre 50 e $80 \%$ da superfície do lago. Os valores de biomassa variaram entre 34,2 g PS. $\mathrm{m}^{-2}$, registrado em maio (outono) e 170,9 g PS. $\mathrm{m}^{-2}$ em janeiro (verão). A maior taxa de produtividade primária foi $3,3 \mathrm{~g} \mathrm{PS} \cdot \mathrm{m}^{-2} \cdot \mathrm{d}^{-1}$ foi registrada em Junho. As concentraçóes de carbono, nitrogênio e fósforo na planta variaram entre: $403 \mathrm{e} 551 \mathrm{~g}$. $\mathrm{kg}^{-1}$, 13,4 e 25,7 g. $\mathrm{kg}^{-1}$ e 0,5 e 1,9 g. $\mathrm{kg}^{-1}$, respectivamente. Os valores da relação N:P na coluna de água variou entre 19:1 e 368:1. Conclusáo: A cobertura da superfície do lago por A. filiculoides durante todo o período do estudo e o seu estado nutricional demonstram sua importância na ciclagem dos nutrientes neste ambiente aquático. A maior relação N:P na coluna de água quando comparada a outro ambiente próximo sem a presença desta macrófita, apoia a ideia de que $A$. filiculoides pode ser a responsável pelo enriquecimento do lago por meio da atividade de fixação biológica de nitrogênio.

Palavras-chave: produção primária, macrófitas flutuantes, carbono, fósforo, nitrogênio. 


\section{Introduction}

The role of aquatic macrophytes in providing food and shelter to fish and invertebrates, cycling nutrients and other elements, stabilizing flow conditions and driving primary production in lakes, rivers and coastal ecosystems worldwide has been recognized (Carr et al. 1997; Trindade et al., 2010; Kerr et al., 2011). In shallow lakes, the vegetation furnishes a refuge from predation for small animals, prevents the resuspension of the sediment and changes the nutrient dynamics of the system (Scheffer, 1998).

Azolla filiculoides Lam. is a free-floating aquatic macrophyte with a broad geographical distribution. It is found in aquatic ecosystems in tropical, subtropical and warm temperate regions (Sculthorpe, 1985), inhabiting still waters with little flow and clay sandy or fertile soils (Pott and Pott, 2000). Azolla species fix atmospheric nitrogen in association with the cyanobacterium Anabaena azollae (Kannaiyan and Venkataramanan, 1985; Carrapiço, 2006; Pereira et al., 2006) and are highly productive (Arora and Singh, 2003).

Because the macrophyte's requirement for nitrogen is satisfied by the symbionts, phosphorus becomes the most important nutrient (i.e., is limiting) for Azolla (Biswas et al., 2005). A phosphorus deficiency results in a general failure of metabolism in plants and the ensuing production of pigments (Adalberto et al., 2004). In contrast, a high concentration of $\mathrm{P}$ increases $\mathrm{C}$ and $\mathrm{N}$ accumulation by the plant and stimulates the plant's growth, favoring the development of blooms (Carrapiço et al., 2006; Cheng et al., 2010). The vigorous vegetative propagation of this species allows it to double every 3-6 days, and the species can quickly cover the surface of aquatic systems (Pott and Pott, 2000).

Due to efficient, rapid growth with high rates of nitrogen fixation, species of Azolla have been used extensively and effectively instead of mineral fertilizers in rice fields in Asia for centuries (Biswas et al., 2005). The contribution of Azolla as biofertilizer has been the focus of many studies (Lumpkin and Plucknett, 1980; Wagner, 1997; Macale et al., 2002; Singh et al., 2010). The plant has also been studied as a habitat for invertebrates (Albertoni et al., 2005) and as a biological filter for purifying water (Toledo and Penha, 2011).

The coastal plain of Rio Grande do Sul State contains a variety of continental aquatic ecosystems, including streams, coastal and inland lakes and large expanses of wetlands (Prellvitz and Albertoni, 2004;
Albertoni et al., 2005; Trindade et al., 2009). These environments are characterized by shallow waters that favor the development of extensive and diverse stands of aquatic macrophytes, especially in the coastal zone (Trindade et al., 2010). Approximately 400-500 species of macrophytes are recognized in Rio Grande do Sul State, and 37.5\% are unique to the coastal plain region (Irgang and Gastal Junior, 1996).

Azolla filiculoides is commonly found in different environments in southern Brazil, occurring in areas of rice cultivation, wetlands, ponds and small water bodies (Pedralli et al., 1985; Irgang and Gastal Junior, 1996; Rolon and Maltchick, 2004; Trindade et al., 2010). Knowledge of biological and ecological aspects of this species could facilitate use of the plant as a natural fertilizer in the region. The objective of this study was to describe the temporal variation in biomass and in the nutritional status of A. filiculoides in a small dystrophic shallow lake.

\section{Material and Methods}

\subsection{Study area}

Negro Lake is located on the campus of the Universidade Federal do Rio Grande (FURG) $\left(32^{\circ} 04^{\prime} 43^{\prime \prime} \mathrm{S}\right.$ and $\left.52^{\circ} 10^{\prime} 03^{\prime \prime} \mathrm{W}\right)$ in the city of Rio Grande, Rio Grande do Sul State, Brazil (Figure 1). Negro Lake is small and round, has a surface area of approximately 0.5 ha and is shallower than $3 \mathrm{~m}$. The lake is surrounded by Eucalyptus sp. This vegetation produces a constant input of leaves, and it shades the lake. During this study, Azolla was the most abundant macrophyte, covering more than $50 \%$ of the surface area of the lake. The peaks of macrophyte biomass occurred during January and June, when Azolla covered approximately $80 \%$ of the surface of the lake. The regional climate is humid subtropical ( $C f a$ according to the Köppen classification) and is characterized by intense humidity during the winter and spring and by dry weather during the summer.

\subsection{Methodology}

Field sampling was performed monthly from November 2000 through October 2001. Biomass determination was performed according to Westlake $(1963,1969)$. All samples were restricted to an area of approximately $20 \mathrm{~m}^{2}$ in the lake littoral zone. In this area, the stand was always visually monospecific and homogeneous in cover and density. Estimates of mean biomass were calculated based on 3 plots. The plots were $0.3 \mathrm{~m}$ in diameter and were sampled 


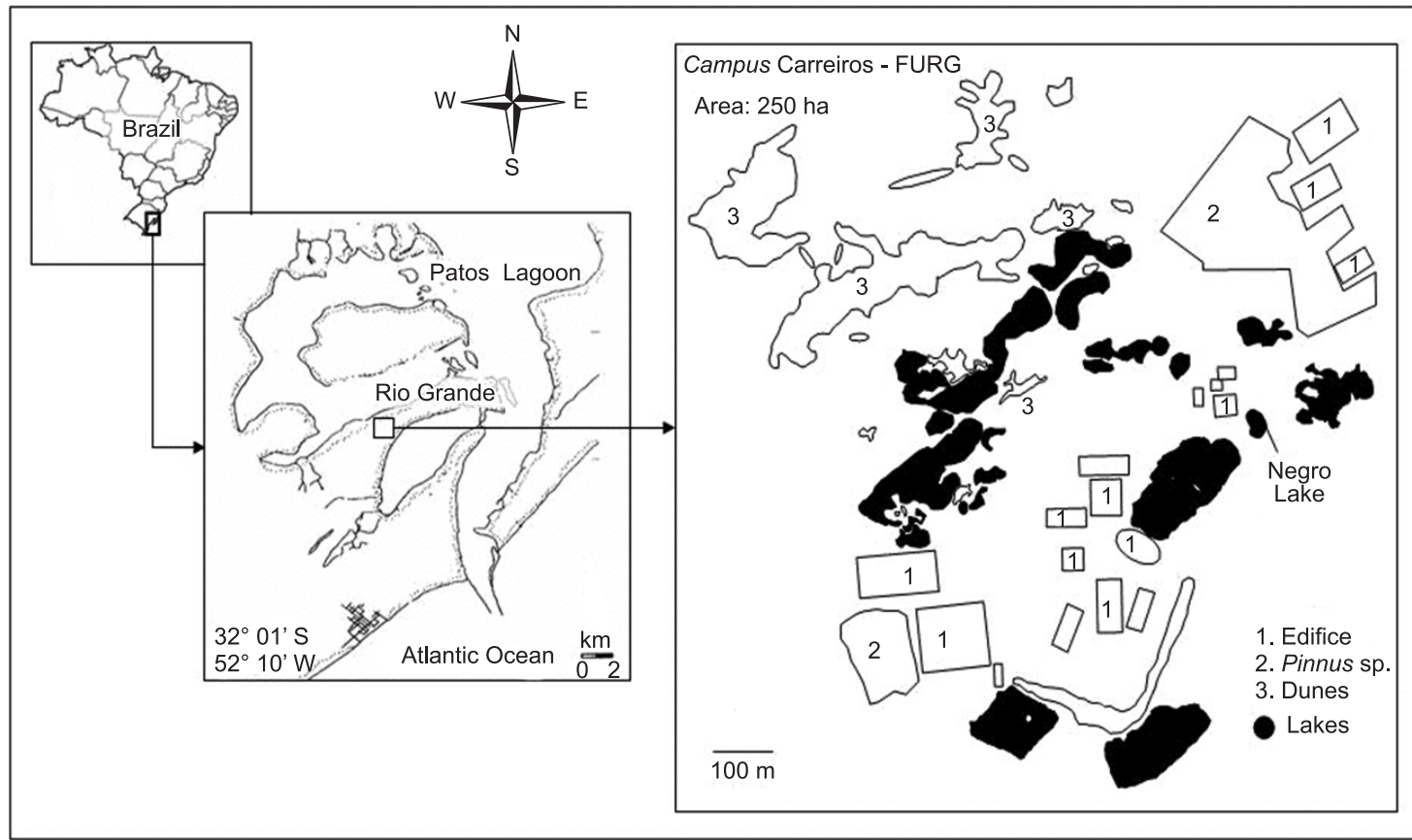

Figure 1. Location of Negro Lake (Carreiros Campus, FURG). Rio Grande, Rio Grande do Sul State, Brazil.

randomly. The coverage of $A$. filiculoides was visually determined.

The samples of $A$. filiculoides were washed with tap water and oven-dried at $60^{\circ} \mathrm{C}$ for approximately 72 hours to reach a constant weight (allowing the material to become brittle to the touch) for the assessment of dry weight (DW). The DW values are expressed in grams per square meter $\left(\mathrm{g} D W \cdot \mathrm{m}^{-2}\right)$. Net primary production (NPP) was determined according to Tieszen (1989) and Pozer and Nogueira (2004). According to this method, macrophyte productivity is calculated by determining the biomass difference between two consecutive samples and dividing this difference by the time in days between the two samples. The results are expressed in $\mathrm{g}$ DW. $\mathrm{m}^{-2} \cdot \mathrm{d}^{-1}$.

Carbon was determined using the dichromate oxidation method, nitrogen was determined with the micro-Kjeldahl method (Allen et al., 1974), and phosphorus was determined with the spectrophotometric method (Tedesco et al., 1995). The biomass results for all nutrients are expressed in g. $\mathrm{kg}^{-1}$ of dry weight. The chemical analysis of the plant biomass was performed by the soil laboratory of the Federal University of Pelotas.

The limnological variables, including dissolved oxygen (DO), temperature $(\mathrm{T}), \mathrm{pH}$, electrical conductivity (EC), total carbon (TC) total nitrogen (TN) and total phosphorus (TP), were summarized from the results in Albertoni et al. (2005), obtained at the same locality and during the same period. The air temperature and hours of solar radiation were obtained from the Meteorological Station - FURG.

Statistical analysis was performed with InStat 3.0 software GraphPad ${ }^{\mathrm{TM}}$. A linear correlation was used to analyze the relationships between the limnological and climate variables and the biomass and nutrient values for the macrophyte.

\section{Results}

The values of the environmental variables, water nutrient content and $\mathrm{N}: \mathrm{P}$ ratio are presented in Table 1 . The lowest solar radiation was recorded in June (97.4 hours) and the highest in December (253.2 hours). The seasonal air temperature values were $20.7^{\circ} \mathrm{C}$ (spring), $24.7^{\circ} \mathrm{C}$ (summer), $17.6^{\circ} \mathrm{C}$ (autumn) and $16.1{ }^{\circ} \mathrm{C}$ (winter). The seasonal water temperature values were $18.5^{\circ} \mathrm{C}$ (spring), $24.3^{\circ} \mathrm{C}$ (summer), $18.8^{\circ} \mathrm{C}$ (autumn) and $11.8^{\circ} \mathrm{C}$ (winter). The dissolved oxygen concentrations remained between $2.4 \mathrm{mg} . \mathrm{L}^{-1}$ (in January) and $5.8 \mathrm{mg} . \mathrm{L}^{-1}$. The $\mathrm{pH}$ values ranged from 5.5 (May) to 6.5 (January) and were slightly acid throughout the study. The electrical conductivity reached its minimum value in September $\left(98.9 \mu \mathrm{S} . \mathrm{cm}^{-1}\right)$ and its maximum in December $\left(131.9 \mu \mathrm{S} . \mathrm{cm}^{-1}\right)$ (Table 1). The water TN was very high, with values between 770 and $4100 \mu \mathrm{g} . \mathrm{L}^{-1}$. The water TP ranged from 10 to $70 \mu \mathrm{g} \cdot \mathrm{L}^{-1}$. The $\mathrm{N}: \mathrm{P}$ ratio of the water ranged from 19:1 (October) to 368:1 (June).

The total biomass values, net primary production, and nutrient status are shown in Table 2. During 
Table 1. Environmental variables during the study period.

\begin{tabular}{lccccccccc}
\hline \multicolumn{1}{c}{ Date } & AT & SR & WT & DO & pH & EC & TN & TP & N:P \\
\hline November & 19.6 & 227.9 & 20.5 & 5.0 & 6.1 & 119.3 & 2540 & 10 & $254: 1$ \\
December & 22.5 & 253.2 & 24 & 4.0 & 6.3 & 131.9 & 2260 & - & - \\
January & 24.7 & 227.7 & 24.5 & 2.4 & 6.5 & 120.0 & 2540 & 30 & $85: 1$ \\
February & 24.9 & 194.1 & 24.5 & 2.4 & 6.2 & 123.0 & 2540 & 70 & $36: 1$ \\
March & 24.5 & 192.3 & 21 & 3.5 & 6.0 & 124.7 & 4100 & 40 & $103: 1$ \\
April & 20.4 & 163.0 & 18 & 3.3 & 6.0 & 126.4 & 3530 & 20 & $177: 1$ \\
May & 16.3 & 108.7 & 17.5 & 2.6 & 5.7 & 125.1 & 3530 & 30 & $118: 1$ \\
June & 16.0 & 97.4 & 10 & 5.8 & 5.9 & 112.0 & 3680 & 10 & $368: 1$ \\
July & 14.5 & 125.2 & 10.5 & 5.0 & 6.0 & 103.5 & 3090 & 26 & $118: 1$ \\
August & 17.6 & 168.4 & 15 & 3.1 & 5.8 & 102.3 & 840 & 20 & $42: 1$ \\
September & 16.4 & 127.2 & 15 & 5.1 & 5.7 & 98.9 & 950 & 40 & $24: 1$ \\
October & 19.9 & 154.3 & 20.5 & 3.6 & 5.5 & 115.9 & 770 & 10 & $19: 1$ \\
\hline AT:Air temp & & & & & & & & &
\end{tabular}

AT: Air temperature $\left({ }^{\circ} \mathrm{C}\right)$; SR: solar radiation (hours); WT: Water temperature $\left({ }^{\circ} \mathrm{C}\right) ; \mathrm{DO}$ : dissolved oxygen $\left(\mathrm{mg} . \mathrm{L}^{-1}\right)$; EC: electrical conductivity $\left(\mu S . \mathrm{cm}^{-1}\right)$; TN: total nitrogen $\left(\mu \mathrm{g} . \mathrm{L}^{-1}\right)$; TP: total phosphorus $\left(\mu \mathrm{g} . \mathrm{L}^{-1}\right)$; N:P: ratio nitrogen and phosphorus of the water; $(-)=$ were not measured (Albertoni et al., 2005).

Table 2. The biomass (B), net primary production (NPP), nutrient concentration (carbon, nitrogen and phosphorus) and C:N:P ratio of Azolla filiculoides.

\begin{tabular}{|c|c|c|c|c|c|c|}
\hline \multirow{2}{*}{ Month } & \multirow{2}{*}{$\begin{array}{c}\text { B } \\
\text { g DW.m-2 }\end{array}$} & \multirow{2}{*}{$\begin{array}{c}\text { NPP } \\
\text { g DW.m-2 } \cdot d^{-1}\end{array}$} & \multicolumn{3}{|c|}{ Nutrients concentration $\left(\mathbf{g} \cdot \mathbf{k g}^{-1}\right)$} & \multirow[t]{2}{*}{$C: N: P$} \\
\hline & & & C & $\mathbf{N}$ & $\mathbf{P}$ & \\
\hline November & 78.3 & 0.0 & 490 & 25.7 & 1.4 & $350: 18: 1$ \\
\hline December & 141.2 & 3.0 & 482 & 20.5 & 1 & $482: 21: 1$ \\
\hline January & 170.9 & 1.1 & 457 & 17.4 & 0.8 & $571: 22: 1$ \\
\hline February & 102.4 & -2.5 & 455 & 13.4 & 0.5 & $910: 27: 1$ \\
\hline March & 124.2 & 0.8 & 403 & 14.6 & 0.6 & $672: 24: 1$ \\
\hline April & 45.0 & -2.8 & 443 & 18.4 & 1.1 & 403:17:1 \\
\hline May & 34.2 & -0.4 & 551 & 23.4 & 1.5 & $367: 16: 1$ \\
\hline June & 110.7 & 3.3 & 477 & 22.1 & 1.9 & $254: 12: 1$ \\
\hline July & 98.4 & -0.5 & 459 & 21.1 & 1.6 & $292: 13: 1$ \\
\hline August & 72.4 & -1.1 & 483 & 21.8 & 1.4 & $358: 16: 1$ \\
\hline September & 54.9 & -0.8 & 481 & 22.3 & 1.0 & $476: 22: 1$ \\
\hline October & 85.1 & 1.1 & 461 & 19.5 & 1.2 & $381: 16: 1$ \\
\hline
\end{tabular}

the study, $A$. filiculoides always covered more than $50 \%$ of the surface area of the lake. In January and June, when the biomass values were higher, this macrophyte covered approximately $80 \%$ of the surface of the lake.

The greatest biomass values were registered during the warmest months (summer), with values ranging from $78.3 \mathrm{~g} \mathrm{DW} \cdot \mathrm{m}^{-2}$ (November) to $170.9 \mathrm{~g}$ DW.m ${ }^{-2}$ (January). During this period, a net primary productivity of $3.0 \mathrm{~g}$ DW. $\mathrm{m}^{-2} \cdot \mathrm{d}^{-1}$ was recorded in December. In January, the net primary productivity was $1.1 \mathrm{~g} \mathrm{DW} \cdot \mathrm{m}^{-2} \cdot \mathrm{d}^{-1}$. The smallest biomass value was recorded in May (34.2 $\left.\mathrm{g} \mathrm{DW} \cdot \mathrm{m}^{-2}\right)$. In June, the biomass was $110.7 \mathrm{~g} \mathrm{DW} \cdot \mathrm{m}^{-2}$. A productivity of $3.3 \mathrm{~g} \mathrm{DW} \cdot \mathrm{m}^{-2} \cdot \mathrm{d}^{-1}$, the greatest value observed during the study, was recorded in June. The biomass values showed a significant positive correlation with air temperature $\left(\mathrm{r}^{2}=0.34\right.$, $\mathrm{p}=0.0435)$ and with the number of hours of solar radiation $\left(\mathrm{r}^{2}=0.33, \mathrm{p}=0.0501\right)$.

The biomass carbon concentration ranged from 403 to $551 \mathrm{~g} \cdot \mathrm{kg}^{-1}$, and the nitrogen concentration ranged from 13.4 to $25.7 \mathrm{~g} \cdot \mathrm{kg}^{-1}$. The phosphorus concentration showed marked variation, with a minimum value of $0.5 \mathrm{~g} \cdot \mathrm{kg}^{-1}$ (February) and a maximum value of $1.9 \mathrm{~g} \cdot \mathrm{kg}^{-1}$ (June). The biomass N:P ratio ranged from 12:1 (June) to 27:1 (February). The biomass showed a negative correlation with the water TP $\left(\mathrm{r}^{2}=0.37, \mathrm{p}=0.0357\right)$. A negative correlation was also found between the water TP and the biomass TP $\left(r^{2}=0.55, p=0.0093\right)$. The values of TN in the water showed no correlations with the biomass or the concentration of TN in the plant tissue. 


\section{Discussion}

The primary productivity of aquatic macrophytes is controlled by several factors, including temperature, photosynthetically active radiation, water level, nutrients and organic carbon availability (Camargo et al., 2003). In temperate regions, macrophytes are influenced primarily by variations in light and temperature. In the tropics, the development of the macrophyte community can be virtually constant, with growth and death of individuals throughout the whole year, or it can exhibit variations that depend on pulses of flooding. For example, large differences in the seasonal dynamics of the primary productivity of macrophytes occur in flood plains in Brazil and other tropical areas (Piedade et al., 1997; Esteves, 1998; Biudes and Camargo, 2008).

The metabolic rate of a plant depends on the temperature and is higher at elevated temperatures. Higher temperatures favor primary productivity by increasing the rates of metabolic chemical reactions. Accordingly, an ideal temperature exists for each species. At its ideal temperature, a species can function most effectively (Carr et al., 1997; Biudes and Camargo, 2008).

The ideal temperature varies among and within species, both seasonally and geographically. The occurrence of such variation underscores the need to study plant growth within a natural setting and over the course of a season (Carr et al., 1997). Previous studies of Azolla showed the importance of temperature for growth and nutrient incorporation (Sah et al., 1989; Cary and Weerts, 1992; Cheng et al., 2010). A study that compared the productivity of different Azolla species found a biomass production of $4.65 \mathrm{~g}$ (wet weight) for A. filiculoides over 14 days at a temperature of $30 \pm 2{ }^{\circ} \mathrm{C}$ (Arora and Singh, 2003). In our study, A. filiculoides occurred in the lake throughout the year. Positive correlations occurred between biomass, productivity and air temperature. However, the highest value of productivity for $A$. filiculoides was $3.3 \mathrm{~g} \mathrm{DW} \cdot \mathrm{m}^{2} \cdot \mathrm{d}^{-1}$, during June. The second highest value of productivity, $2.99 \mathrm{~g} \mathrm{DW} \cdot \mathrm{m}^{2} . \mathrm{d}^{-1}$, occurred in December. The finding of high productivity in a period other than the summer months could be explained by an atypical winter with moderate air temperatures. It is probable that the growth season of the macrophyte began during this period. Results of studies of primary production in different groups of aquatic macrophytes have demonstrated high levels of interspecific variation. Emergent and floating species generally show higher values of primary production than submersed species and species with floating leaves (Camargo et al., 2003).

Plant growth in fresh water is limited by the availability of essential nutrients, at least during the growing season. The two principal nutrients that determine plant growth are nitrogen and phosphorus (Crawley, 1997; Esteves, 1998). The principal source of nutrients for A. filiculoides is the water column. Most of the nitrogen in the tissues of the plant results from biological fixation performed by cyanobacteria (Arora and Singh, 2003; Cheng et al., 2010). Phosphorus is the principal limiting nutrient (Sah et al., 1989; Biswas et al., 2005). Rapid growth of another species, $A$. caroliniana, was observed at high concentrations of phosphorus. The metabolism associated with symbiotic nitrogen fixation by A. caroliniana-Anabaena azollae declined due to the stress induced by phosphorus deficiency, and the reduction in the nitrogen-fixing cyanobacteria caused lower levels of nitrogen to accumulate in the tissues (Adalberto et al., 2004). The importance of $\mathrm{P}$ limitation was also found by a study of the growth of $A$. filiculoides in different habitats with various phosphorus levels. Substantial variation in productivity occurred, with values between 2.55 and $25.8 \mathrm{~g} \mathrm{DW} \cdot \mathrm{m}^{-2} \cdot \mathrm{d}^{-1}$ (Costa et al., 1997).

In our study, the highest productivity was $3.3 \mathrm{~g} \mathrm{DW} \cdot \mathrm{m}^{-2} \cdot \mathrm{d}^{-1}$. We found a significant inverse correlation between phosphorus values in the water column and biomass. This result showed that if the plant increases the amount of this nutrient in the tissues, the availability of the nutrient decreases in the environment. The high coverage of the lake surface by $A$. filiculoides (more than $50 \%$ throughout the year) supports the hypothesis that this macrophyte is important for nutrient regulation in this ecosystem. However, the lack of a correlation between water nitrogen and plant nitrogen suggested that this nutrient is supplied through symbiosis with cyanobacteria. Many studies have demonstrated the capacity of macrophytes to accumulate $\mathrm{N}$ and $\mathrm{P}$. These results highlight the importance of the macrophyte compartment for nutrient cycling. In the water column of the floodplain lakes of the Central Amazon, 2.6 times more $\mathrm{N}$ and 3.6 times more $\mathrm{P}$ occurred in the tissues of macrophytes than in the water (HowardWilliams and Junk, 1977). In the Lobo reservoir in the State of São Paulo, Brazil, 3-6 times more N and 10-13 times more $P$ occurred in the tissues of several macrophytes than in the water (Barbieri and Esteves, 1991). Higher concentrations of $\mathrm{N}$ and $\mathrm{P}$ $\left(\mathrm{N}=26.5 \mathrm{~g} \cdot \mathrm{kg}^{-1}\right.$ and $\left.\mathrm{P}=8.7 \mathrm{~g} \cdot \mathrm{kg}^{-1}\right)$ in the biomass 
were found by Upadhyay et al. (2007) in a study of Azolla pinnata in sewage treatment ponds in India. It was also emphasized that intraspecific variation may be associated with the trophic characteristics of aquatic environments (Da Silva et al. 1994; Henry-Silva and Camargo, 2002).

Variations in the Redfield ratio are commonly used to infer the identity of the limiting nutrient in phytoplankton studies, and this relationship has been expanded for aquatic macrophytes. Freshwater macrophytes in highly fertile environments have an average $N: P$ of $15: 1$, whereas those macrophytes found in less fertile environments have a ratio of 30:1 (Gerloff and Krombholz, 1966). A N:P ratio greater than 30 indicates a phosphorus deficiency, and a N:P ratio less than 10 indicates a nitrogen deficiency (Atkinson and Smith, 1983). Certain factors could affect this ratio. For example, a constant input of phosphorus from the discharge of sewage frequently produced low N:P ratios (e.g., $\mathrm{N}: \mathrm{P}$ ratios in Chara spp. Ranging from 19:1 to 47:1) (Palma-Silva et al., 2004). In view of the N:P reference ratios presented in Atkinson and Smith (1983), we suggest that $A$. filiculoides showed no deficiency of either $\mathrm{N}$ or $\mathrm{P}$.

The high N:P ratios found in the water column of Negro Lake are not common in the aquatic environments of the region. N:P ratios differing from these values were detected in Biguás Lake at the time of the study. This lake lacks populations of A. filiculoides and is located approximately $100 \mathrm{~m}$ from Negro Lake (Palma-Silva et al., 2008). In Biguás Lake, the N:P ratio varied between 8:1 and 21:1 (Palma-Silva et al., 2008). In contrast, the N:P ratios for Negro Lake range between 19:1 (October) and 368:1 (June).

The variation in the biomass and nutritional status of $A$. filiculoides demonstrated the role of the plant in nutrient storage. The N:P ratio did not indicate any nutrient deficiency during the study. The amounts of nitrogen in the biomass were similar to those found in studies of another species of Azolla. The substantial development and presence of $A$. filiculoides throughout the year and the surface coverage of $A$. filiculoides in the lake support the view that the increased $\mathrm{N}$ level in the water column of the lake could be a result of $\mathrm{N}$ fixation via symbiotic activity. This perspective highlights the importance of $A$. filiculoidesin nutrient cycling in shallow aquatic environments.

\section{Acknowledgements}

We would like to thank CAPES for a scholarship for the first author during this research.

\section{References}

ADALBERTO, PR., MASSABNI, AC., GOULART, AJ., MONTI, R. and LACAVA, P. 2004. Efeito do fósforo na captação de minerais e pigmentação de Azolla caroliniana Willd. (Azollaceae). Revista Brasileira de Botânica, vol. 27, p. 581-585.

ALBERTONI, EF., PALMA-SILVA, C. and VEIGA, CC. 2005. Estrutura da comunidade de macroinvertebrados associados às macrófitas aquáticas Nymphoides indica e Azolla fliculoides em dois lagos subtropicais (Rio Grande, RS, Brasil). Acta Biológica Leopoldensia, vol. 27, no. 3, p. 137-145.

ALLEN, S., GRIMSHAW, M., PARKINSON, JA. and QUARMBY, C. 1974. Chemical analysis of ecological materials. Oxford: Blackwell Scientific Publications; London Edinburgh Melbourne. 565 p.

ARORA, A. and SINGH, PK. 2003. Comparison of biomass productivity and nitrogen fixing potential of Azolla Spp. Biomass and Bioenergy, vol. 24, p. 175-178. http://dx.doi.org/10.1016/S09619534(02)00133-2

ATKINSON, MJ. and SMITH, SV. 1983. C:N:P ratios of benthic plants. Limnology and Oceanography, vol. 28, p. 568-574. http://dx.doi.org/10.4319/ lo.1983.28.3.0568

BARBIERI, R. and ESTEVES, FA. 1991. The chemical composition of some aquatic macrophyte species and implications for the metabolism of a tropical lacustrine ecosystem - Lobo Reservoir, Sáo Paulo, Brazil. Hydrobiologia, vol. 213, p. 133-140. http:// dx.doi.org/10.1007/BF00014999

BISWAS, M., PARVEEN, S., SHIMOZAWA, H. and NAKAGOSHI, N. 2005. Effects of Azolla species on weed emergence in a rice paddy ecosystem. Weed Biology and Management, vol. 5, no. 4, p. 176-183. http://dx.doi.org/10.1111/j.14456664.2005.00177.x

BIUDES, JFV. and CAMARGO, AFM. 2008. Estudos dos fatores limitantes à produção primária por macrófitas aquáticas no Brasil. Oecologia Brasiliensis, vol. 12, no. 1, p. 7-19.

CAMARGO, AFM., PEZZATO, MM. and HENRYSILVA, G. 2003. Fatores limitantes à produção primária de macrófitas aquáticas. In THOMAZ, SM. and BINI, ML. Ecologia e manejo das macrófitas aquáticas. Maringá: EdUEM. p. 59-83.

CARR, GM., DUTHIE, HC. and TAYLOR, DW. 1997. Models of aquatic plant productivity: a review of the factors that influence growth. Aquatic Botany, vol. 59, p. 195-215. http://dx.doi.org/10.1016/ S0304-3770(97)00071-5 
CARR, GM., DUTHIE, HC. and TAYLOR, DW. 1997. Models of aquatic plant productivity: a review of the factors that influence growth. Aquatic Botany, vol. 59, p. 195-215.http://dx.doi.org/10.1016/S03043770(97)00071-5

CARRAPIÇO, F. 2006. Is the Azolla-Anabaena symbiosis a co-evolution case?. In Proceedings of the International Conference "General Botany: Traditions and Perspectives", 2006. Department of Botany of the Kazan University.

CARY, PR. and WEERTS, PGJ. 1992. Growth and nutrient composition of Azolla pinnata R. Broown and Azolla filiculoides Lamarck as affected by water temperature, nitrogen and phosphorus supply, light intensity and pH. Aquatic Botany, vol. 43, p. 163-180. http://dx.doi.org/10.1016/03043770(92)90041-G

CHENG, W., SAKAI, H., MATSUSHIMA, M., YAGI, K. and HASEGAWA, T. 2010. Response of the ?oating aquatic fern Azolla ?liculoides to elevated $\mathrm{CO} 2$, temperature, and phosphorus levels Hydrobiologia, vol. 656, p. 5-14. http://dx.doi. org/10.1007/s10750-010-0441-2

COSTA, ML., SANTOS, MC., CARRAPIÇO, F. 1997. Biomass characterization of Azolla filiculoides grown in natural ecosystems and wastewater. Hydrobiologia, vol. 415 , p. 323-327.

CRAWLEY, MJ. 1997. Plant ecology. 2nd ed. New York: Blackwell Science. 717 p.

DA SILVA, CJ., NOGUEIRA, F. and ESTEVES, FA. 1994. Composição química das principais espécies de macrófitas do Lago Recreio Pantanal Matogrossense (MT). Revista Brasileira de Biologia, vol. 54, no. 4, p. 617-622.

ESTEVES, FA. 1998. Fundamentos de Limnologia. 2nd ed. Rio de Janeiro: Interciência; FINEP. 545 p.

GERLOFF, GC. and KROMBHOLZ, PH. 1966. Tissue analysis as a measure of nutrient availability for the growth of angiosperm aquatic plants. Limnolology and Oceanography, vol. 11, p. 529-537. http://dx.doi. org/10.4319/lo.1966.11.4.0529

HENRY-SILVA, GG. and CAMARGO, AF. 2002. Valor nutritivo de macrófitas aquáticas flutuantes (Eichhornia crassipes, Pistia stratiotes e Salvinia molesta) utilizadas no tratamento de efluentes de aqüicultura. Acta Scientiarium Biological Sciences, vol. 24, p. 519-526.

HOWARD-WILLIAMS, C. and JUNK, WJ. 1977. The chemical composition of Central Amazonian Aquatic Macrophytes with special reference to their role in the ecosystem. Archives fur Hydrobiologie, vol. 79, p. 446-464.

IRGANG, BE. and GASTAL JUNIOR, CVS. 1996. Macrófitas aquáticas da Planície Costeira do Rio Grande do Sul. Porto Alegre. 295 p.
KANNAIYAN, S. and VENKATARAMANAN, S. 1985. Influence of nitrogen and phosphorus fertilizers on ammonia-assimilating enzymes of Azolla. Plant and Soil, vol. 88, p. 271-273. http://dx.doi.org/10.1007/ BF02182453

KERR, JG., BURFORD, M., OLLEY, J. and UDY, J. 2011. Nitrogen and phosphorus storage in contrasting reaches of a sub-tropical river system. Water Air Soil Pollut, vol. 217, p. 523-534. http:// dx.doi.org/10.1007/s11270-010-0606-7

LUMPKIN, TA. and PLUCKNETT, DL. 1980. Azolla: Botany, Physiology and Use as a Green Manure. Economic Botany, vol. 34, no. 2, p.111-153. http:// dx.doi.org/10.1007/BF02858627

MACALE, MAR., VLEK, PLG. and SAN VALENTIN, GO. 2002. The Role of Azolla Cover in Improving the Nitrogen Use Efficiency of Lowland Rice. In: Proceedings of the International Symposium Sustaining Food Security and Managing Natural Resources in Southeast Asia, 2002. Thailand. p. 8-11.

PALMA-SILVA, C., ALBERTONI, EF. and ESTEVES, FA. 2004. Charophytes as a reservoir of nutrients and energy in a tropical coastal lagoon subject to human impact (RJ, Brazil). Brazilian Journal of Biology, vol. 64, p. 479-487. http://dx.doi.org/10.1590/ S1519-69842004000300011

PALMA-SILVA, C., ALBERTONI, EF., TRINDADE, CRT. and OLIVEIRA, SS., 2008. Nymphoides indica (L.) O. Kuntze (Menyanthaceae) em um pequeno lago raso subtropical (Rio Grande, RS). Iheringia, Série Botânica, vol. 63, no. 2, p. 249-256

PEDRALLI, G., IRGANG, BE. and PEREIRA, CP. 1985. Macrófitas aquáticos do município de Rio Grande, Rio Grande do Sul, Brasil. Agros, vol. 20, no.1, p. 45-52.

PEREIRA, I., RITA, O., PAZ, AC. and CARRAPIÇO, F. 2006. Discovering Azolla. Symbiosis Teaching Workshop. In Proceedings of the V International Symbiosis Society Congress, 2006. Vienna. p. 4-10.

PIEDADE, MTF., JUNK, WJ. and LONG, SP. 1997. Nutrient dynamics of the highly productive C4 macrophyte Echinocloa polystacha on the Amazon floodplain. Functional Ecology, vol. 1, p. 299-316.

POTT, VJ. and POTT, A. 2000. Plantas aquáticas do Pantanal. Brasília: Embrapa Comunicação para Transferência de Tecnologia; Corumbá: Centro de Pesquisa Agropecuária do Pantanal. 404 p.

POZER, CG. and NOGUEIRA, F. 2004. Flooded native pastures of the northern region of the Pantanal of Mato Grosso: biomass and primary productivity variations. Brazilian Journal of Biology, vol. 64, no. 4, p. 859-866. http://dx.doi.org/10.1590/S151969842004000500016

PRELLVITZ, LJ. and ALBERTONI, EF. 2004. Caracterizaçáo temporal da comunidade de macroinvertebrados associados a Salvinia spp. 
(Salviniaceae) em um arroio da planície costeira do Rio Grande do Sul, RS. Acta Biologica Leopoldensia, vol. 26, p. 213-223.

ROLON, AS. and MALTCHIK, L. 2004. Richness and distribution of aquatic pteridophytes in wetlands of the State of Rio Grande do Sul (Brazil). Acta Limnologica Brasiliensia, vol. 16, no. 1, p. 51-61.

SAH, RN., GOYAL, SS. and RAINS, DW. 1989. Interactive effects of exogenous combined nitrogen and phosphorus on growth and nitrogen fixation by Azolla. Plant and Soil, vol. 117, p. 1-8. http://dx.doi. org/10.1007/BF02206251

SCHEFFER, M. 1998. Ecology of Shallow Lakes. New York: Chapman \& Hall. 357 p.

SCULTHORPE, CD. 1985. The Biology of Aquatic Vascular Plants. London: Edward Arnold. 610 p.

SINGH, SS., MISHRA, AK. and UPADHYAY, RS. 2010. Potentiality of Azolla as a suitable P-biofertilizer under salinity through acid phosphatase activity. Ecological Engineering, vol. 36, p. 1076-1082. http:// dx.doi.org/10.1016/j.ecoleng.2010.04.022

TEDESCO, MJ., GIANELLO, C., BISSANI, CA., BOHNEN, H. and VOLKWEISS, SJ. 1995. Análises de solo, plantas e outros materiais. 2nd ed. Porto Alegre: UFRGS. 174 p.

TIESZEN, LL. 1989. Produção primária e acumulação de biomassa. In: COOMBS, J. and HALL, DO., eds. Técnicas de Bioprodutividade e Fotossintese. Fortaleza: Ediçōes UFC. p. 44-49.

TOLEDO, JJ. and PENHA, JB. 2011. Performance of Azolla caroliniana Willd. and Salvinia auriculata
Aubl. On fish farming effluent. Brazilian Journal of Biology, vol. 71, no. 1, p. 37-45. http://dx.doi. org/10.1590/S1519-69842011000100007

TRINDADE, CRT., FURLANETTO, LM. and PALMA-SILVA, C. 2009. Nycthemeral Cycles and Seasonal Variation of Limnological Factors of a Subtropical Shallow Lake (Rio Grande, RS - Brazil). Acta Limnologica Brasiliensia, vol. 21, p. 35-44.

TRINDADE, CRT., PEREIRA, AS., ALBERTONI, EF. and PALMA-SILVA C. 2010. Caracterização e importância das macrófitas aquáticas com ênfase nos ambientes límnicos do campus carreiros - FURG, Rio Grande, RS. Cadernos de Ecologia Aquática, vol. 5, no 2, p. 1-22.

UPADHYAY, AR., MISHRA, VK., PANDEY, SK. and TRIPATHI, BD. 2007. Biofiltration of secondary treated municipal wastewater in a tropical city. Ecological Engineering, vol. 30, p. 9-15. http://dx.doi. org/10.1016/j.ecoleng.2006.09.004

WAGNER, GM. 1997. Azolla: a review of its biology and utilization. The Botanical Review, vol. 63, p. 1-26. http://dx.doi.org/10.1007/BF02857915

WESTLAKE, DF. 1963. Comparisons of plant productivity. Biological Reviews, vol. 38, p. 385425. http://dx.doi.org/10.1111/j.1469-185X.1963. tb00788.x

WESTLAKE, DF. 1969. Sampling techniques and methods for estimating quantity and quality of macrophytes biomass. In VOLLENWEIDER, RA., ed. A manual on methods for measuring primary production in aquatic environments Oxford: Blackwell. p. 25-32. (IBP Handbook, no. 12).

Received: 11 May 2011

Accepted: 02 April 2012 